\title{
New goods demand patterns in digital economy environment: The case of electric vehicles in Russia
}

\author{
Svetlana Bozhuk ${ }^{1}$, and Nataliia Krasnostavskaia ${ }^{1, *}$ \\ ${ }^{1}$ Peter the Great St. Petersburg Polytechnic University, Saint Petersburg, Russia
}

\begin{abstract}
The trend of using electric vehicles is changing the automotive industry. Electric cars are becoming the most environmentally friendly replacement for combustion vehicles. Knowing the preferences of potential consumers will allow developing effective solutions to create demand for this product. Generating demand should be based on estimating its potential and shaping the consumer profile of this type of transport for market of each country. New goods need special methods to generate demand, since their potential buyers have difficulties in purchase decision making. This paper presents results of a study on prospects in Russia for such new goods as electric vehicles. The study identified factors that ultimately determine the interest of those Russian consumers who have the financial ability to purchase electric vehicles in the near future in electric vehicles. The study demonstrates that consumer prejudices are still there against difficulties in operating electric vehicles. The study confirmed that a number of factors affect the purchase of an electric car in Russia. Expanding the presence of electric vehicles in carsharing companies will significantly improve experience in using this type of transport by potential users. Generating the demand for electric vehicles by applying influence marketing tools is the one of the best solutions.
\end{abstract}

Keywords: electric vehicles, electric cars, digital marketing, demand, consumer behavior

\section{Introduction}

The problem of energy saving is becoming more and more urgent in the world [1,2]. Electric car technology is gaining momentum thanks to the rapid depletion of fossil fuels, as well as environmental concerns. Government programs significantly motivate the development of the electric vehicles market in different countries. Lobbying for conversion of intra-city commercial and urban public transport to electric drive might provide a considerable growth in demand for electric vehicles. However, in Russia, the vector of government support for eco-friendly transport is aimed at financing the gas-fuelled automobile industry. In such difficult market conditions, the main demand for electric vehicles is generated by individual

\footnotetext{
${ }^{*}$ Corresponding author: krasnost_nv@spbstu.ru
} 
consumers. Therefore, generating such demand should be based on estimating its potential and shaping the consumer profile of this type of transport for the Russian market.

Automobile manufacturers aim to bring the electric vehicles price offer to the price level of vehicles with conventional internal-combustion engines. Prospects for the Russian electric vehicles market depend substantially on the awareness of representatives of the younger generation, those to choose their own automobiles in the near future, of the advantages of these vehicles.

The digital economy is developing and consumer behaviour is changing [3, 4]. The authors in their scientific papers addressed the issues of consumer preferences and the choice of electric cars. Knowing consumer preferences and electric vehicle needs is key to developing user-friendly solutions for today's sustainable automotive industry.

The role of customer experience was explored and it was demonstrated how this experience affects the adoption willingness of battery electric vehicles. The mean values of the subjective norm, perceived behavioural control, attitudes, and adoption willingness of experienced consumers are significantly higher than those of inexperienced consumers [5].

The preference for battery electric vehicles as opposed to hybrid electric vehicles or normal combustible vehicles was analysed. Strong evidence that previous experience of driving a battery electric vehicles and car sharing are significant factors to state a preference for electric cars. Other factors such as driving range, purchase price, gender, ecological awareness and incentives such as tax exemptions also influence the choice [6].

Customer purchase intention toward new energy passenger vehicles had a significant, positive relationship with price value, environmental consciousness, quality value, and emotional value. On the contrary, customer purchase intention does not show a significantly positive relationship with social value and government subsidy policy [7].

The Thai car buyers pay attention to the performance factor of electric vehicles (driving range, speed, safety) whilst not being concerned much with the infrastructure (charging facilities) and the financial factors (purchase price, operation and maintenance costs, resale price) of electric vehicles [8].

Potential customers have high expectations regarding the comfort and range of an electric vehicle. One of the most important barriers and obstacles for a broad market uptake are the currently high purchase prices for this new technology [9].

The models are dominated by household characteristics including household income, household size, household vehicle ownership, number of licensed drivers and duration of car ownership. Only two city-level transportation variables have an effect - higher taxi density and higher bus density reducing car purchase. Cold weather, population density gross domestic product per capita positively influence car purchase, while urbanization rate reduces car purchase [10].

Electric car rental may be an effective mode to popularize the electric car, before the cost of the electric car can be reduced substantially [11].

A positive attitude to the choice of an electric car is affected by the use of the different promotion tools especially a test drive.

As electric vehicles become more readily available, sales will depend on consumers' interest and understanding. Electric vehicles rollout has focused too much on technology, and not enough on consumers [12].

The effects of a first-time experience on the evaluation of battery electric vehicles by potential consumers were explored and assessed. The experiment showed that short test drives with battery electric vehicles are a suitable means to support the widespread promotion of electric cars [13].

Vehicle manufacturers should provide customers with more chances to test drive the vehicles, which can give customers direct and true emotional feelings about driving new energy passenger vehicles [14]. 
The authors also investigated the barriers to the purchase of electric cars.

Information on the orientations and perceptions of passenger car enthusiasts and identifies potential socio-technical-economic barriers to the adoption of electric vehicles was provided [15].

It was reviewed how perceived risk factor influences purchase intention referring to electric vehicles. It was examined how perceived risk influences the purchasing mechanism of electric vehicles whilst buying intention is referred to as a main notion within [16].

The major barriers to a more widespread introduction of battery electric vehicles beyond early adopters are the limited range, charging limitations, and costly batteries. An optimization model to estimate the potential for battery electric vehicles to replace one of the conventional cars in two-car households and to viably contribute to the households' driving demand was developed [17].

It is necessary to take into account the fact that electric cars are a relatively new category of products, and most car users have little experience in using them. Also, consumers often have a misconception about electric cars, do not trust them and avoid buying an electric car.

Longitudinal post-adoption data from early adopters of an electric car model was used and showed that consumers' perceptions of innovative aesthetic value buffer the effect of product-related hedonic experience on attitudes towards the product. Innovative consumers are especially sensitive to innovative aesthetic value, so in their co-creation efforts, managers should seek out these customers, because doing so can increase early adopters' long-term product satisfaction and word of mouth, both of which expand the breadth of diffusion for the innovations [18].

It was investigated how Product-Service Systems influence customer acceptance of innovations, since customer acceptance is responsible for the success of innovative products. The main gaps found with electric vehicles are their limited range and high purchase costs. Customers perceive those gaps as less considerable if they rent electric vehicles in a carpool [19].

There is still a mismatch between supply and demand in electric vehicles. Information acceleration in a test studio can improve the traditional approaches of linear acquisition of information about customers and therefore estimation of adequate pricing and commercialisation in an early decision-making phase and can have a positive influence on decision-making behaviour under uncertainty [20].

The industrial dynamics of electric vehicles using product life cycle and eco-innovation concepts were analysed. Large incumbents and start-up firms have targeted different consumer markets with their electric vehicle models. Start-up firms developed electric vehicle models for niche markets (sports cars and low speed vehicles) while large incumbents generally developed electric vehicle models that are more in line with current customer demands [21].

The development of electric vehicle sales depends on the coordinated work of all stakeholders besides direct consumers: the state, car manufacturers and energy suppliers.

Governmental subsidies, environmental policies and effective marketing strategies are needed to support the electric cars market along technological advancements such as improvement in the electric car's battery life [22].

In markets where introduction of modern clean vehicles had been met with supportive policies, their demand has been relatively strong. Factors stated by respondents to influence their opinions of these vehicles included the policy environment, social networks, media influence, and the car-buying experience [23].

The purpose of the study is to determine the portrait of the target audience of electric vehicles in Russia, to identify the factors influencing the purchase of an electric vehicle. 


\section{Methodology}

The study involved 450 respondents over 30 years old. A previous study that looked at potential electric vehicle buyers looked at young people aged 17-30. However, this study focused on those potential buyers who have the necessary financial capabilities to buy a car in the near future.

The study included features that may be divided into feature-factors (10) and resulting features (15).

Lack of experience in using the car creates the consumer's uncertainty when buying it [5, 6]. If a family owns a car, it creates a better consumer understanding of the conditions and requisites for operating a vehicle. In addition, availability of a car is an indirect characteristic of the family income level.

Frequency of the car use is a feature that directly characterizes consumer experience. An unquestionably best solution would be the first-hand experience from driving an electric vehicle. The respondents have no experience of driving electric vehicles in Russia. Trip distance characterizes the need to move. Considering the limited battery mileage of electric vehicles, this feature is an important characteristic. Since the limited trip distance is a barrier to buying an electric vehicle, it is necessary to assess the impact of that feature on consumer intentions. A car being a major purchase, it is rarely made without somebody's recommendation, so was decided to include that feature in the study.

Factors also included the respondent's opinion on reasonable consumption and environmental friendliness of the car: whether it makes sense to have two cars in the family, whether the car is a strong source of pollution. The number of drivers in the household affects the family's striving for diversity of vehicles [10]. In Russia, an electric vehicle is frequently the second or even third car in the family. The authors considered it important to measure this feature during the survey. The consumer's awareness of the environmental impact of the vehicle is significant for displaying interest in purchasing an electric vehicle $[6,14]$. So, this feature was included in the list of features to be measured.

Resultant features (dependent features) reflected the respondents' opinions on the interest, reasons and problems of using an electric vehicle, as well as information on their intention to purchase an electric vehicle.

Respondents' opinions on causes for popularity of electric cars reflect their understanding of the advantages of such vehicles, and their key benefits for the respondent. Consumers' opinions on the potential difficulties of operating electric car provide information on the barriers to such a purchase. It can be assumed that such barriers are: the user's financial limitations (cost of the vehicle), operating conditions (shortage of charging stations and service, weather, state of the roads), electric car performance characteristics (speed and roominess).

One of the reasons for failure of programs promoting electric cars is insufficient information given to customers, so this feature was also included in the study as a purchase barrier [24].

The initial set of features-factors characterizing potential consumers of electric vehicles is presented in Table 1. 
Table 1. Features-factors characterizing potential consumers of electric vehicles

\begin{tabular}{|c|c|c|c|}
\hline $\begin{array}{l}\text { Description of the } \\
\text { feature-factor }\end{array}$ & $\begin{array}{c}\text { Measurement } \\
\text { scale }\end{array}$ & $\begin{array}{c}\text { Number of } \\
\text { categories/values }\end{array}$ & Range of values \\
\hline Gender & Nominal & 2 & Male/female \\
\hline Age & Ratio & - & [over 30 years: $31,32, \ldots$ ] \\
\hline Household income & Interval & 11 & $\begin{array}{c}1-\text { less than } \$ 500 / \text { month } \\
2-\$ 501-\$ 1000 / \text { month } \\
3-\$ 1001-\$ 1500 / \text { month } \\
4-\$ 1501-\$ 2000 / \text { month } \\
5-\$ 2001-\$ 2500 / \text { month } \\
6-\$ 2501-\$ 3000 / \text { month } \\
7-\$ 3001-\$ 3500 / \text { month } \\
8-\$ 3501-\$ 4000 / \text { month } \\
9-\$ 4001-\$ 4500 / \text { month } \\
10-\$ 4501-\$ 5000 / \text { month } \\
11-\text { more than } \$ 5001 / \text { month }\end{array}$ \\
\hline $\begin{array}{c}\text { The presence of a car } \\
\text { in the family }\end{array}$ & Nominal & 2 & Yes/no \\
\hline $\begin{array}{c}\text { Number of cars in the } \\
\text { family }\end{array}$ & Ratio & - & {$[1,2, \ldots]$} \\
\hline $\begin{array}{l}\text { Who influenced the } \\
\text { choice of the car } \\
\text { when buying }\end{array}$ & Nominal & 6 & $\begin{array}{c}\text { Father/mother/ } \\
\text { husband/wife/self/other }\end{array}$ \\
\hline $\begin{array}{l}\text { Frequency of car use } \\
\text { in the family }\end{array}$ & Ordinal & 3 & $\begin{array}{c}1 \text { - every day (frequent) } \\
2 \text { - once or twice a week } \\
\text { (average) } \\
3 \text { - several times a month } \\
\text { (rare) }\end{array}$ \\
\hline $\begin{array}{l}\text { Distance of trips in } \\
\text { the family }\end{array}$ & Ordinal & 3 & $\begin{array}{l}1 \text { - to other cities of Russia, } \\
\text { to other countries (long trips) } \\
2 \text { - no further than to the } \\
\text { countryside (average) } \\
3 \text { - within the city limits only } \\
\text { (short) }\end{array}$ \\
\hline $\begin{array}{l}\text { Whether it makes } \\
\text { sense to have two } \\
\text { cars in the family }\end{array}$ & Ordinal & 3 & $\begin{array}{c}1 \text { - feasible in any case } \\
2 \text { - feasible under certain } \\
\text { conditions } \\
3 \text { - unfeasible }\end{array}$ \\
\hline $\begin{array}{l}\text { Whether the car is a } \\
\text { strong source of } \\
\text { pollution }\end{array}$ & Ordinal & 5 & $\begin{array}{c}1-\text { no, absolutely not } \\
2-\text { no } \\
3 \text { - I can't answer } \\
4-\text { yes } \\
5 \text { - yes, absolutely } \\
\end{array}$ \\
\hline
\end{tabular}

Source: Own processing.

The initial set of resultant features characterizing potential consumers of electric vehicles is presented in Table 2 . 
Table 2. Resultant features characterizing potential consumers of electric vehicles

\begin{tabular}{|c|c|c|c|}
\hline $\begin{array}{l}\text { Description of the } \\
\text { resultant feature }\end{array}$ & $\begin{array}{l}\text { Measurement } \\
\text { scale }\end{array}$ & $\begin{array}{c}\text { Number of } \\
\text { categories/values }\end{array}$ & Range of values \\
\hline \multicolumn{4}{|c|}{ Problems of purchasing electric vehicle in Russia: } \\
\hline $\begin{array}{l}\text { Underdeveloped } \\
\text { infrastructure }\end{array}$ & Nominal & 2 & Yes/no \\
\hline $\begin{array}{l}\text { Severe weather } \\
\text { conditions }\end{array}$ & Nominal & 2 & Yes/no \\
\hline $\begin{array}{c}\text { Poor awareness of } \\
\text { offer in electric } \\
\text { vehicles }\end{array}$ & Nominal & 2 & Yes/no \\
\hline Prohibitive pricing & Nominal & 2 & Yes/no \\
\hline $\begin{array}{l}\text { Limited battery } \\
\text { mileage }\end{array}$ & Nominal & 2 & Yes/no \\
\hline $\begin{array}{c}\text { Complexity of } \\
\text { operation and repair }\end{array}$ & Nominal & 2 & Yes/no \\
\hline Limited roominess & Nominal & 2 & Yes/no \\
\hline Low speed & Nominal & 2 & Yes/no \\
\hline \multicolumn{4}{|c|}{ Important factors when purchasing electric vehicle: } \\
\hline $\begin{array}{c}\text { Developed } \\
\text { infrastructure }\end{array}$ & Nominal & 2 & Yes/no \\
\hline $\begin{array}{l}\text { Special incentives } \\
\text { from government }\end{array}$ & Nominal & 2 & Yes/no \\
\hline Available service & Nominal & 2 & Yes/no \\
\hline Available price & Nominal & 2 & Yes/no \\
\hline $\begin{array}{c}\text { Long range with the } \\
\text { battery }\end{array}$ & Nominal & 2 & Yes/no \\
\hline Attractive design & Nominal & 2 & Yes/no \\
\hline $\begin{array}{l}\text { Personal interest in } \\
\text { purchasing electric } \\
\text { vehicle in the near } \\
\text { future }\end{array}$ & $\begin{array}{l}\text { Interval (Thurstone } \\
\text { scale of equidistant } \\
\text { intervals) }\end{array}$ & 11 & $\begin{array}{c}0-\text { no chance } \\
1 \text { - almost no chance } \\
2-\text { very weak probability } \\
3 \text { - some probability } \\
4-\text { sufficient probability } \\
5 \text { - quite good probability } \\
6 \text { - high probability } \\
7-\text { likely } \\
8 \text { - highly likely } \\
9-\text { almost sure } \\
10-\text { no doubt }\end{array}$ \\
\hline
\end{tabular}

Source: Own processing.

Attributing a feature to a particular type of scale is determined primarily by its content and is of fundamental significance, since the possibility of using a particular data analysis tool depends on it.

The data was analysed using SPSS software. 


\section{Results}

At the first stage of the study, descriptive statistical analysis of each feature was performed. Among the respondents' answers to the question "Personal interest in purchasing electric vehicle in the near future", two options prevailed corresponding to positions on the Thurstone scale of equidistant intervals: $2-3$ and 5-7.

Feature distribution at the 0.01 significance level differs from the normal one, since $\mathrm{p}$ values corresponding to the Shapiro-Wilkes test (W statistics) and D'Agnostino test (K2 statistics) substantially lower than the value pre-set $(0.01)$.

Non-parametric closeness indicators were also calculated: Spearman and Kendall rank correlation coefficients (for ordinal factors), Chuprov and Kramer contingency coefficients (for nominal factors), plus the significance of each factor influence on the result, which was evaluated using the Mann-Whitney test (for alternative factors) and Kruskal-Wallis test (for factors taking more than 2 values).

For nominal features, such as "The presence of a car in the family", "Who influenced the choice of the car when buying", the most frequent values were determined. The vast majority of respondents $(74 \%)$ have a car in their family, and husband, wife are the persons who influenced the choice of the car most frequently $(65 \%)$.

The distribution analysis for the group of alternative features "Problems of purchasing electric vehicle in Russia", which includes 8 alternative features, corresponding to specific barriers to use, identified three main reasons (they were marked by more than $50 \%$ of respondents):

- $\quad$ underdeveloped infrastructure $(72 \%)$,

- prohibitive pricing (67\%),

- severe weather conditions (54\%).

The distribution analysis for the group of alternative features "Important factors when purchasing electric vehicle", which includes 6 alternative features, corresponding to specific barriers to use, identified three main reasons (they were marked by more than $50 \%$ of respondents):

- long range with the battery $(68 \%)$,

- $\quad$ available service $(61 \%)$,

- special incentives from government (59\%).

The results demonstrate proper assessment of conditions and rather good awareness of key problems in operating electric vehicles in Russia. The study confirmed the presence of standard concerns about electric vehicles among the Russian consumers.

Generalizing the results on the paired relations, we may conclude that males develop a stronger intention to purchase an electric vehicle with age 45-50. As for females, the strongest intention to purchase an electric vehicle is at the age 38-43. In general, females are less inclined to purchase an electric vehicle than males.

Those concerned with such problems of using electric vehicles in Russia as "Limited battery mileage", "Limited roominess", "Low speed", are less likely to purchase an electric vehicle among the respondents. On the contrary, those who believe that the key problem with electric vehicle penetration in Russia is "Underdeveloped infrastructure", were more willing to purchase an electric vehicle in the near future.

Summarizing results of the comprehensive statistical data analysis, we can offer the following characteristics of the potential Russian consumer of electric vehicles in Table 3. 
Table 3. Characteristics of the potential Russian consumer of electric vehicles

\begin{tabular}{|c|c|}
\hline Consumer characteristic & Typical value \\
\hline Gender & Male \\
\hline Age & $45-50$ \\
\hline Household income & More than \$3001/month \\
\hline The presence of a car in the family & Yes \\
\hline Number of cars in the family & $1-2$ \\
\hline Who influenced the choice of the car when buying & Member of the family \\
\hline Frequency of car use in the family & Every day \\
\hline Whether it makes sense to have two cars in the family & Feasible in any case \\
\hline Whether the car is a strong source of pollution & Yes \\
\hline Problems of purchasing electric vehicle in Russia & $\begin{array}{c}\text { Underdeveloped } \\
\text { infrastructure }\end{array}$ \\
\hline Important factors when purchasing electric vehicle & $\begin{array}{c}\text { Long range with the } \\
\text { battery }\end{array}$ \\
\hline Personal interest in purchasing electric vehicle in the near future & \begin{tabular}{c} 
High probability \\
\hline
\end{tabular} \\
\hline
\end{tabular}

Source: Own processing.

It should be noted that the results of the multiple correspondence analysis corelate with those from the paired association analysis and the ordinal regression estimation. This makes our conclusions more confident.

\section{Discussion}

In this study, the object of the study was people over 30 years old. People of this age most often have a formed opinion about environmental problem. More than $40 \%$ of the respondents also showed a formed opinion about the problems of transport and issues related to the possible use of electric vehicles.

Electric cars in Russia are perceived as innovative products. Potential consumers are characterized by low awareness of the characteristics of electric vehicles. It should also be noted that at present, programs to raise awareness of potential consumers about the characteristics of electric vehicles are not widely used. Those technological advances that allowed car manufacturers to improve consumer properties of electric vehicles significantly are not known to the lay public.

Given a level playing field, such as vehicle class and price, it can be expected that choosing an electric vehicle is still unlikely. Consumers cite factors as the main problems: underdeveloped infrastructure, prohibitive pricing and severe weather conditions. The provision of electric vehicles as car-sharing vehicles, as well as the expanding use of another electric vehicle, electric scooters, can increase not only the awareness of potential consumers, but also allow them to have their first experience of driving electric vehicles.

The revealed portrait of potential consumers of electric vehicles shows that these people are ready to consider the electric car as a second car, they definitely declare the presence of 
environmental problems, are rational and expect that the use of the electric car will be beneficial.

The study confirmed that a number of factors affect the purchase of an electric car, for example, the presence of a second car in the family.

Characteristics describing the value orientation of consumers showed a stronger influence than socio-demographic characteristics. Supporting responsible consumption and protecting the environment matters for potential consumers of electric vehicles.

\section{Conclusion}

Social media promotion of the idea of electric vehicles should be used to raise awareness and engagement in the purchase. The best solution consists in generating demand for electric vehicles via the influence marketing tools. First, bloggers, as opinion leaders, contribute to raising the audience awareness of offer in electric vehicle and developing its interest in innovation. Second, the product recommendation comes not from the company to the consumer, but from consumer to consumer in that case. It increases significantly consumers' confidence in the information received.

The purpose of the study was to determine the portrait of the target audience of electric vehicles in Russia, to identify the factors influencing the purchase of an electric vehicle. The research objectives for the potential target audience have been achieved. A portrait of the target audience was identified, characteristics that would facilitate the purchase of an electric vehicle in Russia in the future while contributing to the solution of the problems named by the respondents were identified.

This research work was supported by the Academic Excellence Project 5-100 proposed by Peter the Great St. Petersburg Polytechnic University.

\section{References}

1. S. Bozhuk, N. Krasnostavskaia, T. Maslova, N. Pletneva, The problems of innovative merchandise trade in the context of digital environment. IOP Conference Series: Materials Science and Engineering, 497, p. 012115 (2019)

2. S. Bozhuk, T. Maslova, N. Kozlova, N. Krasnostavskaia, Transformation of mechanism of sales and services promotion in digital environment. IOP Conference Series: Materials Science and Engineering, 497, p. 012114 (2019)

3. N. Krasnostavskaia, N. Pletneva, M. Kupriyanova, S. Golovkina, The level of involvement and the nature of the stimulus as factors in the decision-making process on the purchase of handmade goods on the Internet. IOP Conference Series: Materials Science and Engineering, 940, p. 012069 (2020)

4. N. Krasnostavskaia, T. Maslova, L. Ruglova, M. Chigir, Problems of forming marketing competencies in the digital economy. IOP Conference Series: Materials Science and Engineering, 940, p. 012066 (2020)

5. R. Liu, Z. Ding, X. Jiang, J. Sun, Y. Jiang, W. Qiang, How does experience impact the adoption willingness of battery electric vehicles? The role of psychological factors. Environmental Science and Pollution Research, 27(20), 25230-25247 (2020)

6. A. S. Darup, M. Guillen, X. Piulachs, Consumer preferences for electric vehicles in Germany. International journal of transport economics, 45(1), 97-122 (2018)

7. A. Mangmeechai, A. Yuan, Factors Influencing Customer Purchase Intentions towards New Energy Vehicles in China. The International Journal of Interdisciplinary Environmental Studies, 13(1), 1-15 (2018) 
8. T. Thananusak, S. Rakthin, T. Tavewatanaphan, P. Punnakitikashem, Factors affecting the intention to buy electric vehicles: empirical evidence from Thailand. International Journal of Electric and Hybrid Vehicles, 9(4), 361 (2017)

9. J.-A. Bühne, D. Gruschwitz, J. Hölscher, M. Klötzke, U. Kugler, C. Schimeczek, How to promote electromobility for European car drivers? Obstacles to overcome for a broad market penetration. European Transport Research Review, 7(3), 30 (2015)

10. Z. Ling, C. R. Cherry, H. Yang, L. R. Jones, From e-bike to car: A study on factors influencing motorization of e-bike users across China. Transportation Research Part D: Transport and Environment, 41, 50-63 (2015)

11. R. Miao, J. Cao, K. Zhang, B. Chen, Z. Jiang, L. Wang, Value-added path of serviceoriented manufacturing based on structural equation model: the case of electric car rental for instance. International Journal of Production Research, 52(18), 5502-5513 (2014)

12. P. D. Larson, J. Viáfara, R. V. Parsons, A. Elias, Consumer attitudes about electric cars: Pricing analysis and policy implications. Transportation Research Part A: Policy and Practice, 69, 299-314 (2014)

13. F. Hinnüber, M. Szarucki, K. Szopik-Depczyńska, The Effects of a First-Time Experience on the Evaluation of Battery Electric Vehicles by Potential Consumers. Sustainability, 11(24), 7034 (2019)

14. A. Mangmeechai, A. Yuan, Factors Influencing Customer Purchase Intentions towards New Energy Vehicles in China. The International Journal of Interdisciplinary Environmental Studies, 13(1), 1-15 (2018)

15. F. E. Ciarapica, D. T. Matt, M. Rossini, P. R. Spena, Quality, environmental and economic factors influencing electric vehicles penetration in the Italian market. XVIII Summer School "Francesco Turco" 11-13-September-2013, pp. 358-363 (2013)

16. D. Thilina, N. Gunawardane, The effect of perceived risk on the purchase intention of electric vehicles: an extension to the technology acceptance model. International Journal of Electric and Hybrid Vehicles, 11(1), 73 (2019)

17. S. Karlsson, What are the value and implications of two-car households for the electric car? Transportation Research Part C: Emerging Technologies, 81, 1-17 (2017)

18. C. Nagel, J. H. Schumann, Post-adoption buffering effects of innovative product aesthetics. Creativity and Innovation Management, caim.12363 (2020)

19. D. M. Schmidt, F. Braun, S. A. Schenkl, M. Mörtl, Interview study: How can ProductService Systems increase customer acceptance of innovations? CIRP Journal of Manufacturing Science and Technology, 15, 82-93 (2016)

20. H. Proff, T. M. Fojcik, Pricing and commercialisation of electric mobility - dealing with high market uncertainty. International Journal of Automotive Technology and Management, 16(1), 30 (2016)

21. W. Sierzchula, S. Bakker, K. Maat, B. van Wee, The competitive environment of electric vehicles: An analysis of prototype and production models. Environmental Innovation and Societal Transitions, 2, 49-65 (2012)

22. S. W. Lim, K. F. Chen, E. H. Yap, System Dynamics of Electric Cars (EC) Usage and Support Infrastructure in Malaysia. Applied Mechanics and Materials, 627, 342-346 (2014)

23. A. Dini, S. Washington, G. Hawkins, Understanding barriers to consumer demand of plug-in vehicles in Australia. O'Keeffe, B (Ed.) Australasian Transport Research Forum 2013 Proceedings. Australasian Transport Research Forum, Australia, pp. 1-13 (2013)

24. K. Dudenhöffer, Why electric vehicles failed. Journal of Management Control, 24(2), 95-124 (2013) 